\title{
THE RISE OF THE RUSSIAN NOVEL: STUDIES IN THE RUSSIAN NOVEL FROM EUGENE ONEGIN TO WAR AND PEACE. By Richard Freeborn. New York and London: Cambridge University Press, 1973. 289 pp. $\$ 18.50$, cloth. $\$ 8.95$, paper.
}

This is a slim volume for what appears to be an ambitious title, and the number of works examined in any detail to support a study of "the rise of the Russian novel" is few: Eugene Onegin, A Hero of Our Time, Dead Souls, Oblomov, Crime and Punishment, and War and Peace. Yet in a peculiar way Professor Freeborn does what he sets out to do, and we are given a sense of the complexity and scope of the Russian novel between 1830 and 1870. What he has to say is difficult to define and characterize, since he has no thesis, no "theory" of the novel, no special approach, and no astonishing new insights into the rise of the Russian novel. The treatment is multifaceted, flexible, and one might even say random and casual. There is no straining to cover the important works and significant biographical and literary events. We are also spared that mechanical and exhaustive documentation that too often is offered as a substitute for thinking in American scholarship. In a sense he adopts the best of English criticism and is affected only lightly by the worst. The English in their criticism of literature-not only of Russian literature-are by and large less systematic and "holistic" than their American counterparts. They are less occupied with appearing scientific or consistent and more concerned with flexible and personal points of view. At its worst this approach is casual, impressionistic, and even eccentric, as it is surely in Elizabeth Gunn's recent work on Tolstoy; at its best it is an antidote to the Germanic element in American criticism.

Along with Isaiah Berlin, R. F. Christian, and John Bayley, Freeborn is near the best of English scholarship and criticism. His manner is one of informed reticence, a reluctance to overstate, a willingness to entertain other points of view, and a distaste for definitive solutions. A topic is never finished for him, and he always finds room for another point of view. This leads him to give sympathetic and intelligent treatment to points of view he disagrees with, as in his discussion of Belinsky's errors in his criticism of Gogol. The danger of such an approach is losing one's own point of view and never saying anything definite-a danger, however, that does not beset Freeborn, for he is in firm but unobtrusive control of what he is saying. The control shows itself in his conviction that the rise of the Russian novel has much to do with the cultural and historical conditions from which it emerged. $\mathrm{He}$ is too intelligent to see literature as a document, but he is also too intelligent to deny that literature does reflect society in a complex and not fully determinable or discernible way. Freeborn sees the "rise of the Russian novel" as a complex and refracted image of the stresses and contradictions that existed in Russian society, and he gives us tantalizing hints of how these stresses realized themselves on the literary level. He is probably right that $W$ ar and Peace is in part a defensive reflex of the old aristocrat Leo Tolstoy before the attacks of the radicals in the sixties on tradition and vested privilege, and he is surely more than probably right that the reading of Crime and Punishment will be enriched by considering it as a reaction on the part of Dostoevsky to the excesses of the radical and rootless intelligentsia of the sixties. There are further hints about the effect of the state of Russia itself on the rise of the novel, as a physical and social and cultural entity. At least one is Freeborn's continuation of that weird lapse of English criticism for almost a hundred years-Matthew Arnold, Virginia Woolf, Katherine Mansfield, 
and E. M. Forster are among the perpetrators-which leads criticism to exclamations about the Russian soul and the ability of Russian writers to express "life." Freeborn is mercifully touched only lightly by this "exclamatory tradition," and when he feels its pressure he turns it into a kind of admiration for the novelistic tradition that almost justifies those English excesses of "life" and "soul." This is a good book.

\author{
EdWard Wasioler \\ University of Chicago
}

\title{
RANNIE ROMANTICHESKIE VEIANIIA: IZ ISTORII MEZHDUNAROD- NYKH SVIAZEI RUSSKOI LITERATURY. Edited by $M$. P. Alekseev. Leningrad: "Nauka," 1972. 295 pp. 1.55 rubles.
}

K ISTORII RUSSKOGO ROMANTIZMA. Edited by Iu. V. Mann, I. G. Neupokoeva, and U. R. Fokht. Moscow: "Nauka," 1973. 551 pp. 2.48 rubles.

In the second of these collections of studies on Romanticism, E. M. Pulkhritudova reminds us that Realism was once so sacred in Soviet scholarship that "it was often considered direct evidence of progressive social views, a fact which stimulated willy-nilly searches for realistic elements" (p. 39). And this is true. A few short years ago serious study of Russian Romanticism was confined to a small band of scholars in Europe and America, and the number of significant Soviet studies could be counted on the fingers of one hand. Not so today. As Pulkhritudova has also noted, "the exaggeration of realistic tendencies . . . proved to be a temporary phenomenon" (p. 40). The number of Soviet specialists in Romanticism has now grown into an army, and it is difficult to keep up with developments from month to month.

These books-the first one published by the Institute of Russian Literature, the second by the Gorky Institute of World Literature-are new indications that Romanticism has become a major concern in the Soviet Union. The first contains four monographs on key subjects of early Russian Romanticism, and is "the third in a series of efforts undertaken by the Sector of Comparative Russian and Foreign Literatures of Pushkinsky Dom aimed at the systematic study of the history of Russo-European literary relationships" (p. 2). (The two previous collections are Epokha prosveshcheniia and $O t$ klassitsizma $k$ romantizmu.) The second contains a thorough introductory review of recent Soviet scholarship, nine articles under the heading "From Zhukovsky to Lermontov," and another seven under the heading "Later Development of Romanticism (a Few Trends and Tendencies)." Both books have indexes, and the second has a bibliography of works published in the Soviet Union from May 1968 through January 1972 (184 separate listings !). The first is confined to highly specialized studies of early Romanticism, and the second ranges through Romanticism as a period and on to Romanticism as a viable literary practice of later Russian literature. The authors in both works may be counted among the best-known specialists in this literary area. The temptation here is to comment on every contribution; I will limit myself to a few.

After reading $R$. Iu. Danilevsky's "Shiller i stanovlenie russkogo romantizma," it is hard to believe he has left any archival materials untouched, or any other primary or secondary sources unread. He is thoroughly familiar with previous works on this important subject (Peterson, Passage, Kostka, Tschižewskij, Raab, Harder, Gukovsky and Lotman, Smolian, Zhirmunsky, Veselovsky, Tynianov), 